\title{
Aktualisasi Tabiin Perempuan dalam Periwayatan Hadis
}

\author{
Junaid Bin Junaid \\ Dosen Institut Agama Islam Negeri Bone
}

\begin{abstract}
As the second source of Isamic teachings after the Qur'an, the hadith of the prophet Muhammad has provided an accurate understanding of how to comprehend the general contents of the Qur'an. And among those who have made a great contribution to the transmission of hadith is tabiin. tabiins are the third generation after the prophet and the companions. And among the narrations of hadith from among the tabiin, there is also among the women. It can be proved through the actualization of the women in the narration of the hadiths of the prophet well and correctly, thus it will produce a from of actualization that can be accounted for the credibility of the traditions narrated by the women's tabiin.
\end{abstract}

Kata Kunci: Aktualsisasi, Tabiin, Perempuan, Periwayatan Hadis

\section{Pendahuluan}

Term hadis dikenal sebagai sesuatu yang berasal dari Nabi Muhammad saw, baik ucapan, perbuatan, taqrir maupun hal ihwal beliau. Dilihat dari kedudukannya, hadis nabi saw merupakan sumber ajaran Islam yang kedua setelah Al-Quran. Sebagai sumber ajaran kedua, hadis nabi saw memuat berbagai ragam atau topik ajaran Islam yang kandungan isinya dapat dipahami dengan mudah. Akan tetapi, terkadang juga kandungan matannya aneh dan pelik untuk dipahami dari sisi nalar manusia dan ilmu pengetahuan.(H.Nizar Ali:2008).

Oleh karena itu, posisi hadis nabi saw yang menjadi sumber rujukan kedua setelah AlQur'an menunjukkan bahwa begitu kuatnya hadis sebagai fungsi penjelas atau bayan terhadap ayat-ayat Al-Qur'an yang masih bersifat umum. Dalam hal ini, ayat Al-Qur'an tersebut diperinci dengan sabda-sabda rasulullah saw kepada para sahabatnya dan kemudian ditiru oleh para generasi sesudahnya (tabiin) hingga pada masa sekarang.(Saifuddin Zuhri Qudsy dan Ali Imron:2013).

Pada masa tabiin, perkembangan periwayatan hadis telah mengalami satu perubahan yang berkelanjutan. Di mana pada awal periwayatan hadis dari nabi saw masih bersifat sangat dilarang untuk menulis hadis karena Al-Qur'an pada saat itu masih turun dan belum dibukukan 


\section{An-Nisa', Volume XI Nomor 1 Januari 2018}

dalam satu mushaf, walaupun ada sahabat yang menulis hadis tetapi hanya sedikit. Sedangkan pada masa sahabat periwayatan hadis di batas. Dan berkembang pada masa tabiin yang dikenal dengan nama masa menyebarnya periwayat an hadis.(Subhi Sholeh:1969).

Periode tabiin dalam pandangan keagamaan di anggap sebagai salah satu periode yang paling autentik dalam sejarah Islam, yaitu periode terbaik ketiga sebagaimana yang disebutkan Rasulullah saw dalam sabdanya yang memiliki terjemah; "sebaik-baik generasi adalah mereka yang hidup dalam generasiku, kemudian generasi berikutnya (generasi sahabat), kemudian generasi berikutnya (generasi tabiin), dan seterunya, dan seterunya."(HR. Tirmidzi). (Abdul Azis Dahlan et.al.:1996).

Dalam hubungannya dengan kaum perempuan, bahwa pada masa tabiin telah menampakkan keseriusannya dalam meriwayatkan hadis-hadis nabi saw dengan maksimal. Hal ini dibuktikan dengan hadirnya bebreapa periwayat hadis dari kalangan tabiin perempuan. Dan ini merupakan sebuah aktualisasi bahwa para tabiin perempuan tersebut mempunyai peranan yang sangat signifikan terhadap perkembangan periwayatan hadis nabi saw.

\section{Terminologi Tab'in dan Periwayatan Hadis}

Menurut bahasa, tabiin merupakan bentuk jamak dari kata tab'i atau tabi'un. Sedangkan tabi adalah isim fail dari kata tabi'a yang bermakna berjalan dibelakangnya. (Luis Ma'luf:1992).

Sedangkan menurut istilah, tabiin memiliki beberapa definisi yang bersumber dari para ahli hadis. Dalam hal ini diantara pengertian tabiin menurut istilah yang dikemukakan oleh para ahli hadis. Tabiin adalah orang Islam yang hanya bertemu dengan sahabat, berguru kepadanya, tidak bertemu dengan nabi saw dan tidak pula semasa dengan nabi saw.(Hasbi Ashishiddiqie:1989) Tabiin adalah orang yang menjumpai sahabat dalam keadaan beriman dan mati dalam Islam.(Ibnu Hajar al-Asqalany:t.th.).

Menurut Abdul Azis Dahlan, yang dinamakan dengan tabiin adalah harus berjumpa dengan sahabat nabi saw sekalipun dengan sahabat yang termuda (sigar al-sahabah), harus beriman dan meninggal dalam keadaan beragama Islam, dan pertemuan dengan sahabat rasulullah saw bukan hanya sekedar berjumpa dan beriman tetapi harus betul-betul bergaul.(Abdul Azis Dahlan et.al.:1996).

Para ulama ahli hadis membagi generasi tabiin ini dalam beberapa tingkatan berdasarkan senioritas para tabiin itu sendiri dan berdasarkan kualitas sahabat yang pernah 
An-Nisa', Volume XI Nomor 1 Januari 2018

dijumpainya. Dalam hal ini pembagian tersebut berdasar dari segi masa hidupnya tabiin dapat dibagi menjadi tiga kategori (tingkatan), yaitu kibar al-tabiin (tabiin besar) merupakan tabiin yang hidup sebelum akhir abad pertama. A usat al-tabiin (tabiin pertengahan) merupakan tabiin yang hidup antara awal dan pertengahan abad kedua. Sigar al-tabiin (tabiin kecil) merupakan tabiin yang hidup sampai akhir abad kedua.(Dewan Redaksi Ensiklopedi Islam:1994).

Sedangkan keistimewaan dari tabiin tersebut adalah telah menggantikan kedudukan sahabat dalam mengembang tugas keilmuan dan keagamaan. Oleh karena itu mereka patut menerima penghargaan dan penghormatan serta pengakuan tentang keridaan Allah Swt kepada mereka. Dan keistimewaan para periwayat tabiin adalah berlandaskan pada daerah masingmasing setiap tabiin, seperti di Mekkah ada Ata bin Abi Rabah, di Madinah ada Abu Salamah bin Abdur Rahman bin Auf, dan lain sebagainya.

Adapun pengertian periwayat menurut bahasa adalah berasal dari kata dasar riwayat yang memiliki makna dengan menceritakan, mengabarkan, cerita, dan kabar.(Luis Ma'luf:1992). Sedangkan menurut Istilah riwayat adalah kabar yang berisi ucapan, prilaku, atau lain-lain yang dikatakan dari sahabat nabi saw, baik kabar itu benar ataupun tidak. (Muh. Ajaj al-Khatib:1971). Dan yang dimaksud dengan periwayatan hadis adalah para periwayat hadis yang telah memberikan berita atau kabar yang berhubungan langsung dengan hadis yang bersumber dari nabi saw, sahabat, dan tabiin. dan berita atau periwayatan tersebut ada yang valid dan tidak valid.

Seorang perawi yang adil harus memiliki karakteristik moral baik, muslim, telah baligh, berakal sehat, terbebas dari kefasikan dan hal-hal yang menyebabkan harga dirinya jatuh dai ia meriwayatkan hadits dalam keadaan sadar. Dan Karakter yang terdapat dalam diri seorang perawi, mendorongnya agar selalu melakukan hal- hal postif atau perawi selalu konsisten dalam kebaikan dan mempunyai komitmen yang tinggi terhadap agamanya. Maka dari itu peperawi di tuntut mengetahui atau menguasai isi kitabnya.

Syarat-syarat perawi hadis yang memiliki kredibilitas adalah Berakal, cakap/cermat, adil, dan Islam adalah syarat syarat yang mutlak untuk menjadi seorang peperawi agar riwayatnya dapat diterima . apabila seorang peperawi tidak memenuhi seluruh predikat itu maka hadistnya akan ditolak dan tidak akan dipakai. Oleh para kritikus hadis, baik angkatan lama maupun angkatan baru, keempat syarat tersebut membutuhkan penjabaran lebih lanjut. Syu'bah bin alHajjaj(160 H) pernah ditanya : "Siapakah yang hadistnya terpakai?" Syu'bah menjawab: "Orang yang meriwayatkan hadist dari orang terkenal yang justru tidak mereka 


\section{An-Nisa', Volume XI Nomor 1 Januari 2018}

kenal, hadistnya tidak terpakai. Atau apabila dia salah memahami suatu hadist. Atau bila dia sering melakukan kesalahan-kesalahan. Atau meriwayatkan hadis yang disepakati banyak orang bahwa hadist tersebut salah. Maka hadis-hadis yang diriwayatkan oleh orang seperti itu tidak dipakai. Adapun selainya, boleh diriwayatkan.”(H.Mustafa Yakub:2000)

Tampaknya Syu'bah ingin menegaskan bahwa dua syarat yang harus dipenuhi oleh seorang peperawi bila hadistnya ingin diterima yakni adil dan cermat. Sering melakulan kesalahan berarti tidak cermat, dan menyalahgunakan pemahaman hadist berarti tidak adil. Mengenai persyaratan harus Islam dan berakal, keduanya sudah menjadi syarat penting dan mutlak, sehingga Syu'bah tidak perlu menyebutkanya lagi, sebab tidak bisa kita gambarkan lagi seorang yang adil tapi bukan Islam atau orang yang cermat tapi tak berakal.(Hakim Annaisaburi:2006).

Dengan demikian, bahwa yang dimaksud dengan perawi adalah "orang yang meriwayatkan hadits". Salah satu cabang dari penelitian hadits adalah penelitian terhadap perawi hadits. Baik menyangkut sisi positif maupun sisi negetif perawi. Ilmu ini dikenal dengan istilah ilmu Jarh dan Ta'dil.

\section{Tabiin Perempuan Dalam Periwayatan Hadis}

Sebagai generasi ketiga setelah nabi saw dan sahabat dalam hal periwayatan hadis, bahwasanya pada era tabiin eksistensi perempuan tetap diberikan tempat untuk menindak lanjuti periwayatan-periwayatan hadis nabi saw. Hal ini merupakan bentuk perwujudan bahwa perempuan tetap memiliki satu kelebihan pada aspek ilmu pengetahuan, khususnya tentang periwayatan hadis.

Di antara tabiin dari kalangan perempuan yang memiliki banyak periwayatan hadis adalah sebagai berikut:

\section{a. Hafsah Binti Sirin}

Nama lengkap beliau adalah Hafsah Binti Sirin al-Anshariyah al-Bashriyah dikenal dengan sebutan Ummu al-Huzail. Ia meriwayatkan hadis bukan hanya dari guru-guru yang berjenis kelamin perempuan. Tetapi juga dari guru laki-laki yang beberapa diantaranya bukan merupakan mahromnya. Antara lain dari saudaranya: Yahya, juga meriwayatkan dari Anas ibn Malik (w.93 H.), Ummu 'Athiyah, Abu Dzubyan khalifah ibn Ka'ab, al-Rabi 'bn. Ziyad alHaritsi, Khairah Ummu al-Hasan al-Bashri, dan ia juga meriwayatkan dari Salman ibn. 'Amir. Adapun yang meriwayatkan hadisnya adalah: saudaranya Muhammad, juga Qatadah, Ashim al- 
ahwal, Ayyub, Khalid al-Hidza', Ibn.'Aun, Hisyam ibn. Hissan, dan sebagainya.(Al-Hafidz Abi Fadl Ahmad bin Ali bin Hajar Syihabuddin al-Asqalany al-syafi'i:1996).

Dalam al-Kutub al-Tis'ah, hadis-hadis riwayatnya diperoleh dari tiga orang sahabat yang berdomisili di Bashrah. Ia meriwayatkan dari Anas bin Malik sebanyak 10 hadis, dari Salman ibn 'Amir 44 hadis dan dari Nusaibah binti Ka'ab Ummu Athiyah sebanyak 82 hadis, serta dua hadis ia riwayatkan dari orang yang namanya Mubham . ketiga sahabat yang menjadi gurunya tersebut bermigrasi ke Bashrah setelah Nabi Muhammad saw wafat . hafsah belajar dari ketiga sahabat tersebut setelah mereka berada di Bashrah. Meskipun Hafsha dari suku Anshar, tetapi orangtuanya tidak dikenal sebagai periwayat hadis. Ia merupakan generasi baru periwayat hadis yang bukan berasal dari keluarga Nabi. Hafshah bersama dengan tiga orang saudaranya, Muhammad Ibn Sirin, Anas Ibn Sirin, dan Ma’bad Ibn Sirin, muncul sebagai periwayat hadis hasil binaan para sahabat yang menerapkan system egaliter dalam pengajaran hadis. Para sahabat dalam mengajarkan hadis tempaknya tidak memandang aspek primordial para murid yang mau belajar hadis dari mereka. Mereka juga tidak membedakan jenis kelamin dalam membedakan kesempatan untuk mendapatkan pengetahuan hadis nabi.

Para Ulama menganggapnya sebagai periwayat yang tsiqah. Ibn.Ma'in (w.233 H) menilainya dengan tsiqqah hujjah. Al-'Ijli menyatakan bashriyyah tabi'iyyah. Iyyas ibnMu'awwiyah berkata. " aku tidak melihat ada orang yang lebih mulia dari pada Hafshah". Ibn. Hibban (w.354 H) memasukkannya ke dalam al- Tsiqqat. Hafshah wafat pada $101 \mathrm{H}$ dengan usia 70 tahun. Ia termasuk dalam thabaqah ketiga yakni thabaqah al-wustha min altabiin.

Jumlah hadis riwayatnya jauh di atas rata-rata hadis riwayat pertabiin, yaitu 21,6 hadis. Hanya Imam Malik yang tidak memuat hadis dari Hafsahah. Bukhari memasukkan 25 hadis dalam kitab himpun annya dan merupakan penghimpun yang memasukkan hadisnya yang paling banyak setelah Ahmad ibn Hinbal. Hadis riwayat Hafshah tersebar dalam 50 tema dari 354 tema yang ada dalam al-kutub al-tis'ah.(H.Agung Danarta:2013).

\section{b. Fatimah Biniti Al-Mundziri Ibn Al-Zubayr Ibn Al-Awwam}

Nama lengkap beliau adalah Fatimah Binti al-Mundzir adalah istri Hisyam ibn 'Urwah (w.145 H) ia termasuk dalam rawi hadis thabaqah ketiga, yaitu thabaqah al-wustha min tabiin. Fatimah Binti al-Mundzir dibesarkan dilingkungan keluarga pendukung utama Nabi. AlZubair Ibn Awwam (w.36 H) dikenal sebagai sahabat utama nabi. Ia merupakan pelanjut keluarga sahabat utama nabi dalam meriwayatkan hadis. Meskipun ayahnya, al-Mundzir ibn 


\section{An-Nisa', Volume XI Nomor 1 Januari 2018}

Zubayr (w.64 H) dalam al-kutub al-tis'ah hanya meriwayatkan satu hadis. Ia merupakan pewaris ilmu hadis dari neneknya, Asma binti Abi Bakr (w.100H) istri al-Zubayr ibn.'Awwam. Fatimah meriwayatkan 92 hadis, 91 diantaranya ia riwayatkan Dri istri Hasyim ibn 'Urwah yang juga dikenaL sebagai orang yang banyak meriwayatkan hadis. 1.584 hadis. (Al-Hafidz Abi Fadl Ahmad bin Ali bin Hajar Syihabuddin al-Asqalany al-syafi'i:1996).

Fatimah meriwayatkan hadis dari perempuan, yaitu neneknya: Asma' binti Abu Bakr, Ummu Salamah, Ummu al-mu'minin (w.59 H), dan Amrah binti Abdurrahman (w.98 H) adapun yang meriwayatkan hadisnya adalah: suaminya Hisayam ibn.'Urwah, Muhammad ibn sauqah, dan Muhammad ibn Ismail ibn Yasar.

Al-Ijli mengatakan sebagai "madaniyah, tabi'iyyah, tsiqqah". Ibn.Hibban (w.354 H) memasukkannya ke dalam al-tsiqqah. Menurut Hisyam Ibn Urwah, Fatimah lebih tua darinya 13 tahun, sehingga karenanya Fatimah lahir pada $48 \mathrm{H}$.

Keberadaannya diakui oleh semua penghimpun hadis. Hadis-hadis riwayatnya ditilis disemua al-kutub al-tis'ah. Adapun yang paling banyak adalah musnad Ahmad dengan 28 hadis disusul shahih Bukari dengan 23 hadis. Adapun kitab-kitab lainnya memuat kurang dari 10 hadis.(H.Agung Danarta:2013).

c. Mu'adzah Binti Abdullah

Nama lengkap beliau adalah Muadzah binti 'Abdullah al-'adawiyah Ummu alshuhba' al-Bashriyyah merupakan istri shilah ibn Asyim. Ia merupakan generasi baru periwayat hadis. Bukan keluarga nabi ataupun keluarga sahabat utama nabi. Ia tinggal di Bashrah, tetapi hadis-hadis yang ia ruwayatkan sebagian besar dari Aisyah. Kemungkinan ia belajar hadis dari Aisyah ketika Aisyah berkunjung ke Bashrah untuk beberapa lama dalam persiapan sebelum terjadinya perang jamal. (Al-Hafidz Abi Fadl Ahmad bin Ali bin Hajar Syihabuddin alAsqalany al-syafi'i:1996).

Dalam al-kutub al-tis'ah, ia meriwayatkan hadis dari Aisya sebanyak 81 hadis. Dari Ummu 'Amr binti Abdullah ibn Zubair sebanyak 3 hadis, dari sahabat laki-laki Hisyam ibn 'Amir dua buah hadis. Hadis-hadisnya diriwayatkan oleh Abu Qilabah, Qatadah, Yazid alRisyk, Ayyub, 'Ashim al-Ahwal, Sulaiman ibn Abdullah al-Bashri, Ishaq ibn Sa'id, dan Ummu al-Hasan nenek Abu Bakr al-'Adawiy.

Mu'azah adalah periwayat yang tsiqqah. Ibn Ma'in (w.233 H) berkata : tsiqqah, hijjah, Ibn.Hibban (w. 354 H) memasukkannya ke dalam al- tsiqqat. Mu'adz binti Abdullah 
termasuk dalam thabaqah ketiga. Ia meriwayatkan 86 hadis yang terdapat dalam kitab-kitab berikut ini.

Hanya al-Muwaththa' diantara al-kitab al-tis'ah yang tidak memuat hadisnya. Kitab yang memuat terbanyak adalah musnad Ahmad bin Hanbal dengan 50 hadis. Adapun penyebaran hadisnya tersistribusi dalam 22 tema. (H.Agung Danarta:2013).

d. Hajimah binti Hayy

Nama lengkap beliau adalah Hajimah binti Hayy al-Ashabiyah al-Dimasqiyah yang terkenal dengan nama Ummu Darda'. Ia termasuk kategori tabiin pada tingkat ketiga. Yaitu alwusta' min al-tabiin. (Al-Hafidz Abi Fadl Ahmad bin Ali bin Hajar Syihabuddin al-Asqalany al-syafi'i:1996).

Ummu Darda' adalah istri Abu Darda' yang bermukim di Syam. Ia meriwayatkan hadis dari suaminya Abu Darda'. Akan tetapi ia juga meriwayatkan hadis dari laki-laki lain yang bukan suami dan juga bukan muhrimnya. Di antaranya adalah Salman al-Farisi, Fadhalah bin Ubayd, Abu Hurairah, Ka'ab bin Ashim. Selain juga meriwayatkan dari ummu al-mu'minin Aisyah binti Abu Bakar Ashshiddiq.

Dalam al-Kutubu tis'ah, Ummu Darda' meriwayatkan hadis dari suaminya, Uwaimir bin Malik atau yang lebih dikenal dengan nama Abu Darda' sebanayak 62 hadis. Ummu Darda' juga meriwayatkan hadis dari Ka'ab bin Malik sebanyak tujuh hadis, dan dari Abu Hurairah dua buah hadis.

Ummu Darda' menetap di negeri Syam. Ia menunaikan ibadah haji pada tahun $81 \mathrm{H}$. Ia adalah seorang ahli ibadah. Setiap tahunnya, enam bulan ia menetap di Bayt al-Maqdis, dan enam bulan lainnya menetap di Damaskus. Tidak jelas kapan ia meninggal dunia, tetapi yang jelas setelah tahun $81 \mathrm{H}$. Dalam periwayatan hadis, Ummu Darda' meriwayatkan 71 hadis.

Eksistensi Ummu Darda' sebagai periwayat hadis diakui oleh para penghimpun hadis, terbukti dari penghimpun al-kutubu tis'ah hanya Imam Malik saja yang tidak memasukkan hadis riwayatnya ke dalam kitab himpunannya. Ibnu Majah mendistribusikan hadis riwayat Ummu Darda' ke dalam tema yang paling banyak, yaitu pada delapan tema dari sepuluh hadis yang ia tulis, disusul oleh Abu Dawud pada enam tema dari sebelas hadis, lalu Tirmidzi pada lima tema dari delapan hadis. (H.Agung Danarta:2013).

Tampak sekali, bahwa dari keempat tokoh tabiin dari kalangan perempuan tersebut menandakan bahwa para perempuan telah memainkan peranannya dan kontribusinya terhadap 


\section{An-Nisa', Volume XI Nomor 1 Januari 2018}

periwayatan hadis. Dalam hal ini, aktualisasi daripada perempuan itu sendiri akan selalu terangkat derajatnya dengan adanya ilmu pengetahuan tentang periwayatan hadis yang luas yang dimiliki oleh para tabiin perempuan tersebut. Sehingga akan memberikan satu motivasi yang besar terhadap para perempuan pada zaman kekinian dan masa yang akan datang.

\section{Penutup}

Tabiin merupakan generasi ketiga dalam proses periwayatan hadis setelah nabi saw dan sahabat. Dalam hal ini, tabiin telah banyak memberikan sumbangsih yang besar terhadap perkembangan hadis nabi saw. Hal ini dibuktikan dengan sebuah motivasi yang tinggi dalam menindak lanjuti terhadap apa yang telah dilakukan oleh para sahabat nabi saw dalam proses periwayatan hadis.

Tabiin yang memiliki makna sebagai pengikut daripada nabi saw dan sahabat, bahwasanya dalam sejarah periwayatan hadis telah mengukir berbagai macam prestasi dalam mengembang amanah yang berasal dari generasi kedua, yaitu para sahabat nabi saw dalam hal periwaytaan hadis.

Sebagai bagian dari periwayatan hadis, tentunya tabiin yang dimaksud dalam periwayatan hadis nabi saw ada juga berasal dari kalangan perempuan yang memiliki aktualisasi yang besar dalam periwayatan hadis. Di antaranya adalah Hafsah Binti Sirin, Fatimah Biniti AlMundziri Ibn Al-Zubayr Ibn Al-Awwam, dan Mu’adzah Binti Abdullah.

Dengan adanya beberapa tokoh periwayat hadis dari kalangan perempuan tersebut, membuktikan pada kodrat dan derajat perempuan selalu mendapat tempat yang baik sejak awal mulanya daripada periwayatan hadis nabi saw. Dalam hal ini, para perempuan tersebut merupakan cerminan bagi generasi perempuan selanjutnya dalam meneruskan estafet terhadap penjagaan kemurniaan dan kredibilitas hadis nabi saw, khususnya dalam kajian periwayatan hadis nabi saw. disamping itu pula, memberikan satu gerak yang luas dalam hal mengembangkan ilmu pengetahuan luas bagi para perempuan penganut ajaran Islam pada setiap zaman yang ada. 
An-Nisa', Volume XI Nomor 1 Januari 2018

\section{Daftar Pustaka}

Ali, H. Nizar. Hadis Versus Sains Memahami Hadis-Hadis Musykil. Cet. I; Yogyakarta: Teras, 2008

As-Shiddiqie, Hasbi. Pengantar Ilmu Hadis. Cet. 5; Jakarta: Bulan Bintang, 1989.

Al-Asqalany, Ahmad bin Ali bin Hajar, Fathul Bari. Beirut: Darul Fikr. t.th.

Dahlan, Abdul Azis. et.al. Ensiklopedi Hukum Islam. Jakarta: PT. Ichtiar Baru Van Hoeve. 1996.

Danarta, H. Agung. Perempuan Periwayat Hadis. Cet. I; Yogyakarta: Pustaka Pelajar. 2013.

Dewan Redaksi Ensiklopedi Islam. Ensiklpedi Islam. Jakarta: PT. Ichtiar Baru Van Hoeve.1994.

Al-Khatib. Muh. Ajaj. A ssunnah Qabla Tadwin. Beirut: Darul Fikr, 1971.

------. Ulumul Hadis wa Mustalahuhu. Beirut: Darul Fikr, 1982.

Al-Naisaburi, Al-Hakim. Ma'rifah fi Ulum al-Hadis. Cet. 1; Bandung: Nuansa Cendekia. 2006.

Ma'luf, Luis. Al-Munjid fi al-Lugah wa al-A 'lam. Beirut: Darul Masriq, 1992.

Rahman, Abu Amr Usman bin Abdur. Ulumul Hadis. Madinah: Maktabah al-Islamiyah. 1972.

Sholeh, Subhi. Ulumul Hadis Wa Mustalahuhu. Beirut: Darul Ilmi al-Malayin. 1969.

Suparta, Munzier. Ilmu Hadis. Cet. 2; Jakarta: Rajawali Pers. 2010.

Al-Syafi'i, Al-Hafidz Abi Fadl Ahmad bin Ali bin Hajar Syihabuddin al-Asqalany. Tahzib alTahzib. Cet. I; Beirut: Muassasah al-Risalah. 1996.

Zuhri, Saifuddin. dan Ali Imron, Model-Model Penelitian Hadis. Cet. I; Yogyakarta: Pustaka Pelajar, 2013. 